Anne Bergliot Øyehaug

Institutt for laererutdanning og skoleforskning, Universitet i Oslo

Anne Holt

Institutt for naturvitenskap og teknologi, Høgskolen i Hedmark

\title{
Elevers refleksjoner over naturvitenskapens egenart
}

\begin{abstract}
This paper reports from a study where a teacher and researchers collaborated on designing science teaching promoting scientific inquiry for a group of students (age $11-13$ ). Guided by the Norwegian science curriculum, students were during a two-year intervention period regularly engaged in inquiry-based science learning. The students formed and tested hypotheses, were to various degrees engaged in developing research design and took extensively part in the evaluation of evidence. In connection with each inquiry task, students were encouraged to express their ideas about professional or formal science issues emphasized in the Norwegian science curriculum (Why do scientists form and test hypothesis? What characterizes scientific inquiry? Why do scientists compare results?). Data (video recordings of classroom instructions and interviews in addition to written tests) from four students were collected during a two year period. Results indicate that the students' epistemological beliefs remained fairly naïve through the intervention period, in spite of intensive participation in inquiry learning. The students' lack of epistemological development may be understood in terms of the instructional emphasis on formal epistemology, in favor of practical epistemology.
\end{abstract}

\section{Innledning}

Den norske læreplanen i naturfag (Utdanningsdirektoratet, 2013) vektlegger at elevene skal få kjennskap til naturvitenskapens egenart (Nature of Science, NOS). Under formålet med faget står det:

Lover og teorier i naturvitenskapen er modeller av en sammensatt virkelighet, og disse modellene endres eller videreutvikles gjennom nye observasjoner, eksperimenter og ideer. En viktig del av allmennkunnskapen er å kjenne til at naturvitenskapen er i utvikling, $[\ldots]$

Det blir hevdet at personer som forstår naturvitenskapens egenart er bedre $\mathrm{i}$ stand til å forstå kontroverser (globale klimatrusler, genmodifisert mat, 
alternativ medisin) som de møter i verden utenfor skolen (Kolstø, 2006; Sjøberg, 2009). På mellomtrinnet blir enkelte sider ved naturvitenskapens egenart eksplisitt fremhevet i et av kompetansemålene under hovedområdet Forskerspiren. Der står det at eleven skal kunne samtale om hvorfor det $i$ naturvitenskapen er viktig à lage og teste hypoteser ved systematiske observasjoner og fors $\phi k$, og hvorfor det er viktig å sammenligne resultater. Det forventes altså at elevene før de begynner på ungdomstrinnet skal kunne reflektere over forholdet mellom hypoteser, eksperimenter og data. Imidlertid har forskning vist at elever har begrensede evner til å gjøre slike refleksjoner (Driver, Leach, Millar, \& Scott, 1996; Grosslight, Unger, Jay, \& Smith, 1991). En kan tenke seg at elevers deltagelse i såkalte utforskende arbeidsmåter («inquiry-based instruction»), der de selv deltar i hypotesedanning og tolking av data, vil øke deres evne til å reflektere over naturvitenskapens egenart. Selv om det ikke finnes en spesifikk definisjon på utforskende arbeidsmåter, er det enighet om at dette innebærer at elevene forfølger svar på forskbare spørsmål og sammenlikner sine svar med forskeres kunnskaper om verden (for eksempel Crawford, 2007). Abd-El-Khalick (2013) refererer til flere studier som viser at hvis elever skal få forståelse av naturvitenskapens egenart så kreves strukturert undervisning med muligheter for refleksjon mens elevene arbeider utforskende (for eksempel Khishfe \& Abd-El-Khalick, 2002; Peters \& Kitsantas, 2010; Yacoubian \& BouJaoude, 2010). Andre studier har imidlertid vist at utforskende arbeidsmåter ikke nødvendigvis fører til endringer i elevenes ideer om naturvitenskapens egenart (Linn \& Songer, 1993; Meichtry, 1992; Sandoval \& Morrison, 2003; Wu \& Wu, 2011). Denne artikkelen tar for seg hvordan elever som deltar i en utforskende undervisningspraksis i norsk kontekst utvikler evne til å reflektere over naturvitenskapens egenart.

\section{Elevers naturvitenskapelige epistemologi}

Begrepet epistemologi defineres ulikt i ulik type litteratur, men oppsto innen en gren av filosofi der en var opptatt av hva som karakteriserer kunnskap og tilegnelse av kunnskap. Ofte omtales personlig epistemologi som menneskers oppfatninger om hva som karakteriserer kunnskap og tilegnelse av kunnskap (for eksempel Sandoval, 2005). Perry (1970) gjennomførte en longitudinell studie av studenters epistemologi, og fant at individer utviklet seg fra å se på kunnskap som sikker, rett eller gal til å erkjenne at kunnskap har en iboende usikkerhet. Denne forskningen var ikke fagspesifikk, men la et grunnlag for å kunne klassifisere elevers tanker om naturvitenskapens egenart. Naturvitenskapens egenart (NOS, Nature of Science) er nært knyttet til den filosofiske tilnærmingen til epistemologi. Begrepet brukes ofte for å referere til egenarten ved naturvitenskapelig kunnskap og naturvitenskapelige arbeidsmåter, og det har vært diskusjon om hva som karakteriserer sofistikert forståelse av naturvitenskapens egenart. Naturvitenskapelig epistemologi kan med 
utgangspunkt i personlig epistemologi defineres som elevers oppfatninger om hva som karakteriserer naturvitenskapens egenart.

Sandoval (2005) har på bakgrunn av flere definisjoner av elevers naturvitenskapelige epistemologi (Hogan \& Maglienti, 2001; Lederman, Abd-ElKhalick, Bell, \& Schwartz, 2002) forsøkt å oppsummere perspektivene på naturvitenskapens egenart i fire punkter. Han argumenterer for at disse utgjør et minimumsett av det elever trenger for å kunne utforske naturvitenskapelige problemstillinger, for å forstå at det de holder på med er naturvitenskap og for å bli i stand til å ta begrunnede valg i eget liv:

1. Naturvitenskapelig kunnskap må betraktes som konstruert

2. Naturvitenskapelige metoder kan arte seg svært forskjellig - avhengig av hva som skal undersøkes

3. Naturvitenskapelig kunnskap er av forskjellige typer (teorier, lover, hypoteser)

4. Kunnskapen vi har i naturvitenskapen er mer eller mindre sikker

Disse fire epistemologiske perspektivene kan ivaretas på forskjellige måter $\mathrm{i}$ naturfagundervisningen. I det følgende avsnittet vil vi belyse hvordan elever kan berøre sentrale perspektiver ved naturvitenskapelig epistemologi når de reflekterer over de epistemologiske aspektene som vektlegges eksplisitt i den norske læreplanen for mellomtrinnet; lage og teste hypoteser, produsere og vurdere data og sammenlikne resultater.

Refleksjoner over hypotesedanning kan bidra til at elever utvikler erkjennelse om at naturvitenskapelig kunnskap ikke er endelig (perspektiv 1) og bevissthet om at det er kvalitative forskjeller mellom hypoteser og prediksjoner på den ene siden, og etablert kunnskap i form av lover og teorier på den andre siden (perspektiv 3). Når elevene lager og begrunner hypoteser, må de ta hensyn til teori som allerede er utviklet av andre, og har muligheten til å erkjenne at hypoteser er kvalitativt forskjellig fra etablerte teorier. Carey og Smith (1993) viser til at mange elever ikke forstår at naturvitenskapen er en teoridrevet virksomhet. Slik naturfag ofte undervises, blir det ikke tydelig for elevene at både valg av hypoteser og forskningsdesign i forkant av unders $\varnothing$ kelsen, og tolkingen av resultatene i etterkant, styres av de underliggende og eksisterende teoriene som finnes innenfor feltet. Når det gjelder forskningsmetoder, kan refleksjoner over disse bidra til en erkjennelse om at forskningsmetoden må være relevant for det som skal unders $\emptyset$ kes og dermed at naturvitenskapelige arbeidsmåter varierer (perspektiv 2). Schauble et al. (1995) fant at elever på femte trinn var bedre i stand til å planlegge eksperimenter etter at de hadde lært hva som var hensikten med slike aktiviteter. Videre er det gjort studier som viser at elever får en mer robust forståelse og bedre evne til å gjennomføre undersøkelser når de forstår hvordan naturvitenskapelig kunnskap har utviklet seg (Rudolph, 2005; Wu \& Wu, 2011). Refleksjoner over hvorfor man 
sammenligner resultater fra undersøkelser kan også bidra til at elever erkjenner at kunnskapen vi har i naturvitenskapen kan være mer eller mindre sikker (perspektiv 4). I prinsippet vil det altså være mulig å berøre Sandovals fire epistemologiske perspektiver gjennom refleksjon over de tre arbeidsmåtene (hypotesedanning, forskningsmetoder og sammenlikning av resultater).

Smith et al. karakteriserer elevenes oppfatninger om naturvitenskap i tre nivåer som kvalitativt skiller mellom forskjellige epistemologiske forestillinger (Carey \& Smith, 1993; Smith, Maclin, Houghton, \& Hennessey, 2000; Smith \& Wenk, 2006). Hvert nivå inneholder et sett med begreper for å beskrive både forståelse for kunnskapsstrukturer og tilegnelse av kunnskap i naturvitenskap, fra en naiv Knowledge Unproblematic Epistemology (KUE), via et mellomnivå (INT) som beskriver overgangen mot en avansert Knowledge Problematic Epistemology (KPE).

Sandoval (2005) trekker et skille mellom elevenes epistemologiske ideer om egne unders $\varnothing$ kelser i klasserommet og deres ideer om det «ekte forskere» gjør, og foreslår to måter å kategorisere elevers naturvitenskapelige epistemologi på. På den ene siden definerer han praktisk epistemologi som epistemologiske ideer som elevene anvender når de selv konstruerer naturvitenskapelig kunnskap gjennom utforskende arbeidsmåter. På den andre siden definerer han formell epistemologi som elevers refleksjoner over profesjonell eller formell naturvitenskap. Sandoval argumenterer for at forskning på elevers naturvitenskapelige epistemologi også må inkludere analyser av elevenes tanker om egen utforsking, for på den måten å bygge en bro mellom praktisk og formell epistemologi. Det blir derfor viktig å forstå hvilke spesifikke epistemologiske ideer elevene har om egen utforskende praksis. En slik innsikt kan for eksempel oppnås ved å reflektere over egne naturvitenskapelige metoder (som hypotesetesting, innhenting og tolkning av data og sammenlikning av resultater).

\section{Mål for denne undersøkelsen}

I denne artikkelen presenteres resultater fra en studie der vi har undersøkt hvordan elever som deltar $\mathrm{i}$ en utforskende undervisningspraksis innenfor rammen av den norske læreplanen utvikler evne til å reflektere over naturvitenskapens egenart. Forskningsspørsmålene er:

- Hva karakteriserer utviklingen av elevers naturvitenskapelige epistemologi (refleksjoner over hypotesedanning, forskningsmetoder og sammenlikning av resultater)?

- I hvilken grad berører elever Sandovals fire epistemologiske hovedpunkter i refleksjoner over naturvitenskapens egenart? 


\section{Metode}

Fire elever i én klasse ble fulgt fra den våren de gikk i 5. trinn til våren de gikk i 7. trinn. Datamaterialet er hentet fra fem undervisningsperioder. Forskere og lærer samarbeidet om planlegging av undervisningen og forskere var til stede i all undervisning (hver undervisningsperiode besto av fem-seks hele undervisningsdager). Forskerne hadde ansvar for at sentrale naturvitenskapelige begreper og teorier ble ivaretatt og for at utforskende arbeidsmåter ble brukt. Videre var hensikten også at elevene skulle reflektere over naturvitenskapens arbeidsmåter. Undervisningsplaner ble detaljert utarbeidet for å sikre at de forhåndsdefinerte intensjonene ble realisert. Planene var detaljerte når det gjaldt naturvitenskapelige begreper og arbeidsmåter, men mer generelle når det gjaldt refleksjoner over naturvitenskapelige arbeidsmåter. Selv om det var enighet om at elevene skulle reflektere over hvorfor forskere lager hypoteser og sammenlikner resultater, ble det som oftest ikke planlagt i detalj hvordan dette skulle skje. Læreren hadde ansvaret for gjennomføringen av undervisningen. Forskere var til stede i klasserommet, i hovedsak som observatører og i enkelte tilfeller som medlærere.

Tabell 1 viser hvilke naturvitenskapelige arbeidsmåter som elevene fikk erfaring med og hvordan elevene reflekterte over arbeidsmåter i de ulike periodene. Undervisningen tok sikte på å engasjere elevene både gjennom små eksperimenter og større utforskende arbeid. 
Tabell 1: En oversikt over hvilke naturvitenskapelige arbeidsmåter elevgruppen deltok i og hvordan elevene reflekterte over disse arbeidsmåtene.

\begin{tabular}{|c|c|c|c|c|c|c|}
\hline & Elever & $\begin{array}{l}\text { Periode } 1 \\
\text { (vår 5. trinn og } \\
\text { høst 6.trinn) }\end{array}$ & $\begin{array}{l}\text { Periode 2 } \\
\text { (høst 6. trinn) }\end{array}$ & $\begin{array}{l}\text { Periode } 3 \\
\text { (vår 6. trinn) }\end{array}$ & $\begin{array}{l}\text { Periode } 4 \\
\text { (høst 7. trinn) }\end{array}$ & $\begin{array}{l}\text { Periode } 5 \\
\text { (vår 7. trinn) }\end{array}$ \\
\hline \multirow[t]{2}{*}{$\begin{array}{l}\text { Hypotese- } \\
\text { danning }\end{array}$} & $\begin{array}{l}\text { Laget } \\
\text { hypoteser }\end{array}$ & $\begin{array}{l}\text { Laget hypoteser i } \\
\text { små og store } \\
\text { utforskende } \\
\text { arbeid } \\
\text { Felles } \\
\text { forskningsspørs- } \\
\text { mål og hypotese }\end{array}$ & $\begin{array}{l}\text { Laget hypoteser } \\
\text { i stort } \\
\text { utforskende } \\
\text { arbeid }\end{array}$ & $\begin{array}{l}\text { Laget hypoteser } \\
\text { i små og store } \\
\text { utforskende } \\
\text { arbeid } \\
\text { Felles } \\
\text { forsknings- } \\
\text { spørsmål og } \\
\text { hypotese }\end{array}$ & $\begin{array}{l}\text { Laget hypoteser } \\
\text { i små og } \\
\text { utforskende } \\
\text { arbeid }\end{array}$ & $\begin{array}{l}\text { Laget hypoteser i } \\
\text { små og store } \\
\text { utforskende } \\
\text { arbeid } \\
\text { Selvstendig } \\
\text { forsknings- } \\
\text { spørsmål og } \\
\text { hypotese }\end{array}$ \\
\hline & $\begin{array}{l}\text { Reflekterte } \\
\text { over } \\
\text { hypotese- } \\
\text { danning: }\end{array}$ & $\begin{array}{l}\text { Diskuterte } \\
\text { betydningen av } \\
\text { teori for } \\
\text { forsknings- } \\
\text { spørsmål og det å } \\
\text { lage hypoteser }\end{array}$ & & $\begin{array}{l}\text { Diskuterte } \\
\text { betydningen av } \\
\text { teori for } \\
\text { forskningsspørs } \\
\text { mål og det å } \\
\text { lage hypoteser }\end{array}$ & $\begin{array}{l}\text { Reflekterte over } \\
\text { det det å lage } \\
\text { hypoteser }\end{array}$ & $\begin{array}{l}\text { Reflekterte over } \\
\text { det å lage } \\
\text { hypoteser }\end{array}$ \\
\hline \multirow{2}{*}{$\begin{array}{l}\text { Foreslår } \\
\text { forsknings- } \\
\text { design }\end{array}$} & $\begin{array}{l}\text { Foreslo } \\
\text { forsknings- } \\
\text { metoder }\end{array}$ & $\begin{array}{l}\text { Foreslo } \\
\text { forsknings- } \\
\text { metoder }\end{array}$ & & $\begin{array}{l}\text { Foreslo } \\
\text { forsknings- } \\
\text { metoder }\end{array}$ & & $\begin{array}{l}\text { Foreslo } \\
\text { forsknings- } \\
\text { metoder }\end{array}$ \\
\hline & $\begin{array}{l}\text { Reflekterte } \\
\text { over } \\
\text { forsknings- } \\
\text { metoder: }\end{array}$ & $\begin{array}{l}\text { Diskuterte } \\
\text { betydningen av } \\
\text { feilkilder }\end{array}$ & $\begin{array}{l}\text { Diskuterte } \\
\text { betydningen av } \\
\text { feilkilder }\end{array}$ & $\begin{array}{l}\text { Diskuterte } \\
\text { betydningen av } \\
\text { feilkilder }\end{array}$ & & $\begin{array}{l}\text { Reflekterte over } \\
\text { hvordan (tidligere) } \\
\text { forskere arbeidet } \\
\text { og hvorfor en skal } \\
\text { repetere forsøk }\end{array}$ \\
\hline \multirow[t]{2}{*}{$\begin{array}{l}\text { Behandling } \\
\text { av data }\end{array}$} & Tolket data: & $\begin{array}{l}\text { Tolket data flere } \\
\text { ganger både i } \\
\text { små og stort } \\
\text { utforskende } \\
\text { arbeid }\end{array}$ & $\begin{array}{l}\text { Tolket data kun } \\
\text { få ganger i stort } \\
\text { utforskende } \\
\text { arbeid }\end{array}$ & $\begin{array}{l}\text { Tolket data flere } \\
\text { ganger både i } \\
\text { små og stort } \\
\text { utforskende } \\
\text { arbeid }\end{array}$ & $\begin{array}{l}\text { Tolket data flere } \\
\text { ganger i små } \\
\text { utforskende } \\
\text { arbeid }\end{array}$ & $\begin{array}{l}\text { Tolket data flere } \\
\text { ganger både i } \\
\text { smà og stort } \\
\text { utforskende } \\
\text { arbeid }\end{array}$ \\
\hline & $\begin{array}{l}\text { Reflekterte } \\
\text { over hvorfor } \\
\text { forskere } \\
\text { sammen- } \\
\text { likner } \\
\text { resultater: }\end{array}$ & $\begin{array}{l}\text { Diskuterte } \\
\text { betydningen av } \\
\text { feilkilder og } \\
\text { hvorfor forskere } \\
\text { sammenlikner } \\
\text { resultater }\end{array}$ & $\begin{array}{l}\text { Diskuterte } \\
\text { betydningen av } \\
\text { feilkilder og } \\
\text { hvorfor forskere } \\
\text { sammenlikner } \\
\text { resultater }\end{array}$ & $\begin{array}{l}\text { Diskuterte } \\
\text { hvorfor forskere } \\
\text { sammenlikner } \\
\text { resultater }\end{array}$ & $\begin{array}{l}\text { Diskuterte } \\
\text { hvorfor forskere } \\
\text { sammenlikner } \\
\text { resultater }\end{array}$ & $\begin{array}{l}\text { Diskuterte hvorfor } \\
\text { forskere } \\
\text { sammenlikner } \\
\text { resultater }\end{array}$ \\
\hline
\end{tabular}

Fra periode 1 ble elevene introdusert for begrepet feilkilder. I de tre første periodene løftet lærer ved flere anledningen i helklassedialoger betydningen av feilkilder for tolkning av forskningsresultater. Videre, gjennom hele toårsperioden som studien pågikk, bidro lærer til diskusjoner om hvorfor forskere lager hypoteser og om betydningen av å sammenlikne resultater. Andre trekk ved forskeres arbeidsmåter ble ikke eksplisitt løftet i undervisningen før i periode 5, da elevene reflekterte over hvordan tidligere tiders forskere arbeidet og hvorfor en gjentar fors $\varnothing \mathrm{k}$ ( $\mathrm{i}$ forbindelse med bes $\varnothing \mathrm{k}$ av personer som spilte forskere fra tidligere tider). Enkelte trekk ved naturvitenskapens egenart (feilkilder) ble altså vektlagt sterkere i begynnelsen, mens andre trekk (hvorfor forskere sammenligner av resultater) ble vektlagt sterkere i slutten av toårsperioden som studien pågikk, men uten at det var tenkt en progresjon $\mathrm{i}$ utviklingen av elevenes naturvitenskapelige epistemologi. 


\section{Utvalg}

Studien ble gjennomført i en klasse på en liten skole i landlige omgivelser. Læreren var erfaren, men uten formell naturfaglig kompetanse. Utvalget består av fire av klassens elever og studien følger deres epistemologiske utvikling. Resultater fra intervjuer og tester, publisert i tidligere arbeider, har vist at de fire i gjennomsnitt presterte nær klassens gjennomsnittlige skår. (Øyehaug \& Holt, 2013). De er representative for spredningen i klassen, fordi de har ulike prestasjoner og motivasjon i naturfag. De fire elevene deltok mer eller mindre aktivt $\mathrm{i}$ undervisningen, og det så ut til at de foretrakk ulike arbeidsmåter, og derfor kan sies å representere ulike elevtyper. De to guttene (med fiktive navn Thomas og Martin) deltok begge aktivt i diskusjoner i klassen, foretrakk dialoger og eksperimenter, men ikke skriftlig arbeid. En av dem (Thomas) presterte bedre enn den andre. Thomas var også den desidert mest muntlig aktive. En av jentene (med fiktivt navn Anna) var en typisk høyt presterende elev, som deltok relativt ofte i diskusjoner. Den andre jenta (med fiktivt navn Elisabeth) deltok derimot lite i diskusjoner i klassen, og foretrakk lesing i større grad enn de andre. Hun presterte faglig noe under gjennomsnittet.

\section{Datainnsamling}

Elevsitatene som belyses i denne artikkelen er hentet fra videoopptak av dialoger i klasserommet (ca. 40 timer videomateriale), skriftlige tester og intervjuer med fokusgrupper ved slutten av hver undervisningsperiode og individuelle intervjuer med elevene ved slutten av 7. trinn. Både i intervjuer, $i$ undervisningen og på skriftlige tester ble elevene stilt spørsmål om hvorfor forskere lager hypoteser, hvordan forskere jobber og hvorfor de sammenlikner resultater. Skriftlige tester og intervjuguider var utformet først og fremst for å kartlegge begrepsforståelse og elevenes evne til å lage hypoteser, utarbeide forskningsdesign og tolke data. Både tester og intervjuguide inneholdt derfor kun noen få spørsmål om naturvitenskapens egenart. Gjennomføringen av intervjuene var i tråd med det som defineres som delvis strukturerte intervjuer, hvor spørsmål og tema var fastsatt på forhånd, mens rekkefølgen i intervjuet ikke behøver å følge intervjuguiden (Postholm, 2010; Thagaard, 2009).

\section{Dataanalyse}

Sitater fra dialoger i undervisningen, intervjuer og skriftlige tester der elevene reflekterte over naturvitenskapelige arbeidsmåter ble identifisert og kodet. Sandovals fire epistemologiske perspektiver ble definert som kategorier (tabell 2), og elevsitatene ble analysert i forhold til disse. 
Tabell 2: Kategorier for å identifisere ulike perspektiver på hva som kjennetegner naturvitenskapelig kunnskap og naturvitenskapelige arbeidsmåter (Sandoval, 2005).

\begin{tabular}{|l|l|}
\hline & Epistemologisk perspektiv \\
\hline $\mathbf{1}$ & Naturvitenskapelig kunnskap må betraktes som konstruert \\
\hline $\mathbf{2}$ & $\begin{array}{l}\text { Naturvitenskapelige metoder kan arte seg svært forskjellige - avhengig av hva som } \\
\text { skal undersøkes }\end{array}$ \\
\hline $\mathbf{3}$ & Naturvitenskapelig kunnskap er av forskjellige typer (teorier, lover, hypoteser) \\
\hline $\mathbf{4}$ & Kunnskapen vi har i naturvitenskapen er mer eller mindre sikker \\
\hline
\end{tabular}

Det er også gjort en analyse av hvor sofistikerte elevenes epistemologiske ideer er, fra en naiv Knowledge Unproblematic Epistemology (KUE), via et mellomnivå (INT) som beskriver overgangen mot en avansert Knowledge Problematic Epistemology (KPE) (se tabell 3).

Tabell 3: Kvalitative kjennetegn ved naiv Knowledge Unproblematic Epistemology (KUE), mellomnivå (INT) og en mer avansert Knowledge Problematic Epistemology (KPE), utviklet på bakgrunn av (Smith et al. 2000).

\begin{tabular}{|l|l|}
\hline & Kvalitativ beskrivelse av elevens epistemologiske ideer \\
\hline $\begin{array}{l}\text { Knowledge } \\
\text { Unproblematic } \\
\text { Epistemology } \\
\text { (KUE) }\end{array}$ & $\begin{array}{l}\text { Elevene tror at kunnskap er sann og sikker og at naturvitenskapen er en samling sannheter om } \\
\text { fenomener i naturen (hva som skjer) og konkrete framgangsmåter (hvordan ting skal gjøres). } \\
\text { Elevene differensierer ikke mellom naturvitenskapelige ideer, metoder og resultater. }\end{array}$ \\
\hline $\begin{array}{l}\text { Intermediate } \\
\text { (INT) }\end{array}$ & $\begin{array}{l}\text { Elevene tror at naturvitenskapelig kunnskap består av en samling med testede ideer og at } \\
\text { forskere gjør eksperimenter for å teste ideene for å se om de har rett og for å forkaste eller } \\
\text { endre ideene hvis de finner ut at de tar feil. }\end{array}$ \\
$\begin{array}{l}\text { Elevene har oppfatninger om både hypotesetesting og forklaringer, og skiller mellom } \\
\text { vitenskapelige ideer, aktiviteter og resultater (hensikten med eksperimenter er å teste } \\
\text { forskerens ideer; hensikten med en forklaring er å redegjøre for resultater fra eksperimenter). }\end{array}$ \\
\hline $\begin{array}{l}\text { Knowledge } \\
\text { Problematic } \\
\text { Epistemology } \\
\text { (KPE) }\end{array}$ & $\begin{array}{l}\text { Elevene differensierer ikke mellom hypoteser og teorier. } \\
\text { naturvitenskapelig kunnskap består av godt utprøvde teorier om naturen. De vet at det finnes } \\
\text { ulike naturvitenskapelige metoder. }\end{array}$ \\
& $\begin{array}{l}\text { De betrakter en teori som en felles forståelsesramme for et sett av hypoteser som brukes for å } \\
\text { forklare empiri. Elever ser på teorier som retningsgivende for alt utforskende arbeid: som å } \\
\text { lage hypoteser, valg av metoder og tolke data. }\end{array}$ \\
& \begin{tabular}{l} 
Elevene differensierer mellom forskeres teorier og hypoteser \\
\hline
\end{tabular}
\end{tabular}

\section{Resultater}

Tabell 4 gir en oversikt over hvilke arbeidsmåter (hypotesedanning $(\mathrm{H})$, forskningsmetoder (F) og sammenlikning av forskningsresultater (S)) hver av de fire elevene reflekterte over, og hvilke av Sandovals fire perspektiver (1-4) som de i den sammenhengen berørte i hver av de fem periodene og i sluttintervjuet. 
Tabell 4: Oversikt over hvilke arbeidsmåter (hypotesedanning $(H)$, forskningsmetoder $(F)$ og sammenlikning av forskningsresultater (S)) hver av de fire elevene reflekterte over, og hvilke av Sandovals fire perspektiver (1-4) som de i den sammenhengen berørte i data fra dialoger i undervisningen, intervjuer og skriftlige tester.

\begin{tabular}{|c|c|c|c|c|c|c|}
\hline Elev & Periode 1 & Periode 2 & Periode 3 & \begin{tabular}{|l} 
Periode 4 \\
\end{tabular} & Periode 5 & Sluttintervju \\
\hline Thomas & & $S(4)$ & $H(4)$ & $S(4)$ & $F(4)$ & $F(1)$ \\
\hline Anna & $\begin{array}{l}F(3) \\
F(4)\end{array}$ & & $\begin{array}{l}H(4) \\
S(3)\end{array}$ & $S(4)$ & $F(1)$ & $F(4)$ \\
\hline Martin & $\mathrm{H}(4)$ & & & & $F(3)$ & \\
\hline Elisabeth & $\mathrm{H}(4)$ & & $S \circ g H(4)$ & & & \\
\hline
\end{tabular}

I den videre analysen studeres enkeltsitater, med den hensikt å få fram hver elevs epistemologiske utvikling gjennom de fem undervisningsperiodene.

\section{Thomas}

Thomas deltok aktivt i dialoger knyttet til utforskende arbeidsmåter i alle fem undervisningsperiodene. Han tolket for eksempel data på et stabilt høyt nivå i alle periodene (Øyehaug \& Holt, 2013). I periode 2 sa Thomas imidlertid dette om hvorfor man sammenlikner resultater:

(...) da kan man sjekke hvem som har gjort en god og hvem som har gjort en dårlig jobb

Han viste her en vag forståelse for det å oppdage og eliminere feil, og ser derfor ut til å ha erkjent at naturvitenskapelig kunnskap kan være mer eller mindre sikker (perspektiv 4).

I periode 3 refererte han til hypoteser, testing og det å vise resultatene etterpå da han ble spurt om hvordan en best kan overtale noen i naturfag. Etter denne perioden svarte Thomas følgende på spørsmålet om hva en hypotese er: "Hypoteser er noe du tror". I en test skrev han at hypoteser utformes før eksperimenter for å "styrke" videre utforsking. Det kan se ut som han har en vag forståelse for at kunnskap vil bli mer sikker hvis den brukes til å utforme hypoteser, som deretter kan testes og bidra til å utvikle kunnskapen videre. I intervjuet etter denne perioden uttrykte han videre forståelse for at en hypotese må testes flere ganger for å finne ut om den er riktig. Han foreslo for eksempel å teste en hypotese om at det ikke foregår fotosyntese under vann ved å feste en tråd til en vannlilje for å dra bladet under vann. Det kan se ut til at han har en vag idé om hvorfor forskere lager hypoteser, og en erkjennelse av at naturvitenskapelig kunnskap blir mer sikker hvis den brukes til å utforme hypoteser, som deretter kan testes og bidra til å utvikle kunnskapen videre (perspektiv 4).

I periode 4 sier Thomas følgende om hvorfor forskere sammenlikner resultater: 
Jo, for da finner man den som har mest rett, og kanskje finner at den ene har feil og kanskje finner det beste resultatet

I dette sitatet ser det ut til at han i større grad enn i periode 2 har erkjent at det å sammenlikne resultater kan gjøre at påstander om naturvitenskapelige fenomener blir sikrere (perspektiv 4).

I periode 5 holder han fast ved sitt syn på hensikten med hypotesedanning, og uttaler at "da har man noe å teste opp i mot". Videre svarte han slik da han ble spurt om hvordan en best kan overtale noen i naturfag:

Gi dem en hypotese og så teste den, og så vise dem testen

Igjen er han inne på at naturvitenskapelig kunnskap vil bli mer sikker hvis den brukes til å utforme hypoteser, som deretter kan testes og bidra til å utvikle kunnskapen videre (perspektiv 4). I periode 4 og 5 deltok Thomas også i faglige diskusjoner med personer som spilte rollen som tidligere tiders vitenskapsmenn. En av hensiktene med dramatiseringen var at elevene skulle utvikle forståelse for naturvitenskapelig epistemologi. I et intervju etter siste periode hevdet han at det eneste han lærte fra disse dramatiseringene var historie. I sluttintervjuet uttrykte Thomas dette om hvordan forskere er kommet fram til kunnskap om forbrenning i cellene:

Forskere fra generasjoner bak har funnet det ut (...)

(...) de brente en fyrstikk mens de så inn i et mikroskop... veldig sterkt mikroskop kanskje

Sitatene tyder på at Thomas har erkjent at kunnskap blir til over tid, og at naturvitenskapelig kunnskap er konstruert (perspektiv 1).

Thomas sin uttalelse i periode 2 om sammenligning av resultater (s 9) kan type på at han tror at det finnes én bestemt måte å gjennomføre eksperimenter på som gir det rette svaret. Han ser ut til å befinne seg på et naivt (KUE) refleksjonsnivå. I periode 3 uttrykker han vage ideer om at forskere gjør eksperimenter for å teste ideene for å se om de har rett og for å forkaste eller endre ideene hvis de finner ut at de tar feil. I periode 4 bruker han formuleringen mest rett og berører dermed at naturvitenskapelig kunnskap er mer eller mindre sikker. Igjen tyder dette på at han har ideer om at man tester ideer for å se om de er riktige og forkaster dem hvis de er feil. I sluttintervjuet kan det se ut som at han har erkjent at forskere gjør mange eksperimenter for å teste ideene sine. Det kan se ut til at Thomas i løpet av studien har beveget seg fra et naivt (KUE) refleksjonsnivå mot et mellomnivå (INT). Han viser at han forstår naturvitenskapelig kunnskap som en samling med testede ideer, og han erkjenner at forskere gjør eksperimenter for å teste ideene for å finne ut om de har rett og for å forkaste eller endre ideene hvis de finner ut at de tar feil. 


\section{Anna}

Anna deltok også aktivt i dialogene knyttet til utforskede arbeidsmåter. Hun var den eneste av de fire elevene som gjennomgående begrunnet hypotesene sine med henvisning til naturvitenskapelige teorier og modeller (Øyehaug \& Holt, 2013). Dette ser i noen grad ut til å ha bidratt positivt til hennes refleksjoner over hypotesedanning. Da Anna i periode 1 ble spurt om hva som karakteriserer forskeres arbeidsmåter, svarte hun slik:

Lag hypoteser og prøv å få en begrunnelse for det. Men du kan ikke bare ha en begrunnelse, du må teste det ut og

Det ser ut til at Anna har ideer om at hypoteser krever både begrunnelser (altså teori) og testing, og at hun har en begynnende forståelse av at hypoteser er en egen kategori (perspektiv 3). Samtidig kan det se ut til at hun har en vag erkjennelse om at naturvitenskapelig kunnskap blir mer sikker hvis den brukes til å utforme hypoteser, som deretter kan testes og bidra til å utvikle kunnskapen videre (perspektiv 4).

I periode 2 bidro ikke Anna med refleksjoner over naturvitenskapelige arbeidsmåter, men i en skriftlig test etter periode 3 begrunnet hun hypoteser slik "... når man har noe å gå etter og for at man skal sammenlikne sin hypotese med andres for å finne ut hva som er riktig?’. Det kan se ut til at hun på samme måte som i periode 1 har erkjent at hypoteser krever begrunnelser, og at hun derfor muligens betrakter det som en egen kategori (perspektiv 3). Videre uttalte Anna seg slik om å sammenlikne resultater i periode 3 :

For da kan vi se om det er noe forskjell, se om det er noe forskjell i omgivelsene når vi vet forskjellen og deretter finne ut hva som er mest sannsynlig

I dette sitatet bruker hun begrepet mest sannsynlig om resultater fra eksperimenter, og er dermed inne på at kunnskapen vi har i naturvitenskap er mer eller mindre sikker (perspektiv 4). Etter periode 4 uttrykte hun dette om at forskere sammenlikner resultater:

Siden kan hende at det er forskjellige ulike.. jeg hadde et svar og så var det fem andre som hadde et annet svar, så hadde de likt.. så fem hadde rett. Ikke jeg.

Ved oppfølgingsspørsmål viser det seg at hun her er opptatt av å oppdage og eliminere feil. Det kan se ut til at hun har erkjent at det å sammenlikne resultater kan bidra til at påstander om naturvitenskapelige fenomener blir sikrere (perspektiv 4).

Etter periode 5 uttrykte Anna dette da hun ble spurt om hva hun kunne lære av å få bes $\varnothing \mathrm{k}$ av personer utkledd som vitenskapsmenn fra tidligere tider: 
Det går an å lære hvordan de hadde det. Altså nå får jo vi alle opplysningene, så vi har det mye enklere enn de hadde det på den tiden. Sånn at de kanskje gjorde det litt flere ganger enn oss for å finne det riktige svaret

I sluttintervjuet sa hun dette om hvordan forskere har tilegnet seg kunnskap om forbrenning i cellene:

De kanskje har laga seg hypoteser, og så har de prøvd å finne ut måter å kunne teste ut på (...) De kunne prøvd å veie det, og så prøve å finne ut grunnen til hvorfor det var... var sånn

Det kan se ut til at Anna har erkjent at kunnskap blir til over tid, og at naturvitenskapelig kunnskap er konstruert (perspektiv 1). Videre ser det ut til at hun har vage ideer om hvorfor forskere lager hypoteser, og en erkjennelse om at naturvitenskapelig kunnskap vil bli mer sikker hvis den testes opp mot hypoteser (perspektiv 4). Anna har sannsynligvis en begynnende forståelse for at forskere har gjort mange eksperimenter for å teste ideene sine.

Anna differensierte tidlig (periode 1) mellom forskeres teorier og hypoteser. I periode $1-3$ viste Anna en erkjennelse av at forskere tester ideer for å se om disse er riktige og at de forkaster ideer som er feil. I periode 4 brukte hun ordet rett om resultatene, og i periode 5 sier hun fortsatt at forskerne finner det riktige svaret, og det kan derfor se ut til at hun holdt fast ved oppfatningen om at naturvitenskapelig kunnskap er sikker. Annas naturvitenskapelige epistemologi kan plasseres på et mellomnivå (INT), selv om hun på enkelte områder av naturvitenskapens egenart, viste et mer modent og differensiert syn.

\section{Martin}

Martin deltok aktivt i dialoger knyttet til utforskende arbeidsmåter, men ikke alltid med korrekte og relevante naturvitenskapelige forklaringer og forslag til unders $\varnothing$ kelsesmåter. Han laget for eksempel hypoteser i bare to av periodene, og anvendte da i liten grad naturvitenskapelige teorier (Øyehaug \& Holt, 2013). Videre bidro han lite i refleksjoner over hypotesedanning og sammenlikning av resultatene, men i periode 1 svarte han dette på hvorfor forskere lager hypoteser:

For å sjekke liksom at det er riktig det etterpå når du har tatt forsøket for å se om du har riktig. For du må liksom skrive hypotesen før du gjør oppgaven. For hvis du skriver den etter da er det jo riktig.

Martin berørte dermed at hypoteser kan bidra til at naturvitenskapelig kunnskap blir mer sikker (perspektiv 4). Imidlertid resonnerte han om dette på en upresis og overfladisk måte.

I periode 2 bidro ikke Martin med refleksjoner over naturvitenskapelige arbeidsmåter, men $\mathrm{i}$ et intervju etter periode 3 påsto han at hullet $\mathrm{i}$ ozonlaget fikset seg selv uten at forskeres kunnskap og arbeidsmåter hadde bidratt. Med andre ord uttrykte han en viss skepsis mot naturvitenskapelig forskning. 
Etter periode 4 ble han spurt om hva som er viktig når en skal prøve å overtale noen i naturfag (eksempelvis ved å skrive et brev for å overbevise om et bestemt tiltak for å spare strøm). Martin nevnte kun brukernes synspunkter og det å bruke et overtalende språk som virkemidler i brevet. Selv ved oppfølgingsspørsmål kom han ikke inn på hypotesetesting og datainnsamling.

Etter periode 5 uttrykte Martin dette i en samtale om forbrenning i cellene, og om medisinsk måleutstyr:

Jeg tror egentlig bare at forskere har noen sånne teorier... det er sånn de bare skriver ned

På bakgrunn av dette sitatet ser det ut til at han trodde at det ikke er gjort undersøkelser om forbrenning i cellene. Han ser likevel ut til å ha erkjent at naturvitenskapelig kunnskap er av ulik type, og at teorier har egne karakteristiske trekk (perspektiv 3). Imidlertid foreslår han ikke noe alternativ til naturvitenskapelige teorier.

I sluttintervjuet svarte Martin dette på spørsmål om hvordan forskere for hundre år siden bidro til kunnskapen om forbrenning i cellene:

Det var liksom prøvd ut og litt sånn, men vekt og sånn det tror jeg ikke de hadde..

Videre påpeker han at han lærer mest naturfag av å gjøre fors $\varnothing \mathrm{k}$ fordi:

... da kan du liksom prøve det ut og se om det funker, istedenfor å lese i en faktabok der det står ja eller nei det går ikke.

Det kan se ut til at Martin konsekvent gjennom hele perioden som studien pågikk mente at kunnskap er sann (vi kan ved hjelp av hypotesen kontrollere at det vi har gjort er riktig) og at naturvitenskapen er en samling sannheter om fenomener i naturen. Han mente at teorier er noe som forskere bare tror, og det kom ikke frem noen tydelig differensiering $i$ hans ideer om hypoteser versus teorier. Martin ideer om naturvitenskapens egenart kan i stor grad karakteriseres som naive (KUE).

\section{Elisabeth}

Elisabeth deltok lite i klasseromsdiskusjoner og bidro med refleksjoner om naturvitenskapens arbeidsmåter kun i intervjusammenheng. Data viser at Elisabeth laget hypoteser i kun en av periodene, og at hun i liten grad anvendte naturvitenskapelige begreper og teorier når hun gjorde dette (Øyehaug \& Holt, 2013). I periode 1 svarte hun slik da hun ble spurt om hvorfor man lager hypoteser:

Det er mye bedre å lage hypoteser for å kanskje finne ut hva jeg greier å gjøre riktig og hva du tenkte før du testa det ut og kanskje du tror rett eller du tror galt. 
Det kan se ut til at hun har tilegnet seg en svært vag forståelse av hvorfor det lages hypoteser (hun bruker egne erfaringer fra utforskende arbeid), og en slags erkjennelse om at naturvitenskapelig kunnskap vil bli mer sikker hvis den testes opp mot hypoteser (perspektiv 4).

I periode 2 reflekterte ikke Elisabeth over naturvitenskapelige arbeidsmåter, men i periode 3 hevdet Elisabeth følgende om årsaken til at forskere lager hypoteser:

For å finne ut av ting. Det kan hjelpe deg å finne ut liksom hvordan det er med blomsten og sånn. Hvis vi ikke hadde hypoteser, så visste vi jo ikke hvor du skulle starte og sånn

Her kan det se ut til at hun i noe større grad enn i periode 1 har erkjent at hypoteser kan bidra til at naturvitenskapelig kunnskap blir mer sikker (perspektiv 4). I periode 3 svarte Elisabeth slik på spørsmål om hvorfor forskere sammenlikner resultatene sine: «Hjelpe hverandre, hvis den ene tror den andre har feil, kan de si fra». Her er hun inne på det å oppdage og eliminere feil, og det kan se ut til at hun har erkjent at det å sammenlikne resultater kan bidra til at påstander om naturvitenskapelige fenomener blir sikrere (perspektiv 4).

I periode 4 og 5 bidro hun ikke med refleksjoner over naturvitenskapelige arbeidsmåter, men hun svarte slik da hun i sluttintervjuet ble spurt om hva som karakteriserer forskeres arbeidsmåter:

Ehm. De gjorde undersøkelser. Og testa ut ting. (..)

Elisabeth berører her ingen av de fire epistemologiske hovedpunktene, men sitatet tyder på at hun kun har en begynnende forståelse for at forskere tester ideer for å se om disse er riktige eller forkaster dem hvis de er feil.

På bakgrunn av periode 1, der hun mente at kunnskap er sann og sikker, og periode 3 der hun blant annet sa at hypoteser kan bidra til å finne ut hvordan, kan det tolkes som at hun har hatt en forsiktig utvikling fra naiv (KUE), mot en noe mer nyansert epistemologi (INT). 


\section{Diskusjon}

\section{Elevenes naturvitenskapelige epistemologi}

De fire elevene berørte noen av Sandovals perspektiver på naturvitenskapelig epistemologi i større grad enn andre. Alle elevene var inne på at naturvitenskapelig kunnskap er mer eller mindre sikker (perspektiv 4). Både Thomas og Anna berørte flere ganger perspektiv 4, både da de reflekterte over hypotesedanning og hvorfor forskere sammenlikner resultater. Elisabeth og Martin berørte også perspektiv 4, men sjeldnere enn Thomas og Anna. Thomas og Anna erkjente at hypotesedanning og sammenlikning av resultater kan bidra til at påstander om naturvitenskapelige fenomener blir sikrere. Videre ser det ut til at de begge erkjente at naturvitenskapelig kunnskap ble til over tid (perspektiv 1). Anna og Martin var begge inne på at naturvitenskapelig kunnskap er av forskjellige typer (perspektiv 3). Anna ser ut til å ha erkjent dette når hun $\mathrm{i}$ periode 1 antydet at hypoteser er en egen kategori innen naturvitenskapelig kunnskap. Martins skepsis til teorier i periode 5 viser at han også til en viss grad har erkjent at naturvitenskapelig kunnskap er av forskjellige typer, og at én av disse er naturvitenskapelig teori.

Et hovedfunn er at ingen av elevene i løpet av studien oppnådde en moden og nyansert naturvitenskapelig epistemologi (KPE). Det kan se ut som Thomas utviklet seg fra et naivt (KUE), i retning et noe høyere refleksjonsnivå (INT) mot slutten av studien, mens Anna holdt noenlunde samme refleksjonsnivå (INT) gjennom hele perioden. Martin ser ut til å beholde en naiv forestilling om naturvitenskapens egenart (KUE) gjennom hele toårsperioden, mens Elisabeth ser ut til å ha en svak utvikling fra en naiv forestilling (KUE) i retning av et høyere refleksjonsnivå (INT).

Det kan altså se ut til at det er vanskelig for elevene å reflektere over hensikten med naturvitenskapelige prosesser og over forholdet mellom forskeres ideer, eksperimenter og data. Dette er i tråd med Carey og Smith (1993), som fant at mange elever ikke forstår at naturvitenskapen er en teoridrevet virksomhet.

\section{Mangel på progresjon og praktisk epistemologi}

Noen av refleksjonene de fire elevene gjør kan kobles til den utforskende praksisen som de deltok i. For eksempel brukte Elisabeth erfaringer fra det utforskende opplegget om planter (i periode 3) da hun reflekterte over hypotesedanning. Imidlertid er det tydelig at elevers forståelse av epistemologi ikke kommer av seg selv, bare fordi de arbeider utforskende. Elevene reflekterte ikke over naturvitenskapens egenart, uten at det ble lagt til rette for det. Læreren er sentral for å sette i gang refleksjoner før, underveis og etter utforskende arbeid.

Khifhse og Abd-El-Khalick (2002) fant for eksempel at elever som er involvert i utforskende arbeidsmåter trenger tydelig veiledning for å kunne 
reflektere over erfaringer og observasjoner og for å vurdere epistemologiske implikasjoner. Flere studier har vist at måten læreren leder diskusjoner på under utforskende arbeid har stor betydning for elevenes læring (for eksempel Asay \& Orgill, 2010; Haug, 2013; Minner, Levy, \& Century, 2010). Haug (ibid.) understreker viktigheten av å utnytte læringssituasjonene (det vil si å gjøre «teachable moments» til «learnable moments»). Et eksempel på dette er en lærer som i mange år underviste i utforskende arbeidsmåter og som systematisk stilte spørsmål som fikk elevene til å reflektere over egen kunnskapsbygging (Smith, et al., 2000). Disse elevene uttrykte langt mer sofistikerte epistemologiske ideer enn det som er vanlig for aldersgruppen.

I vår studie var elevene på et relativt lavt refleksjonsnivå. Årsaken kan være at lærer sjelden refererte til naturvitenskapens egenart (NOS) på utfyllende måter mens elevene arbeidet utforskende. Intervjuspørsmål og testspørsmål ble heller ikke stilt i en utforskende kontekst. Videre ble ikke refleksjoner over hypoteser, forskningsmetoder og sammenlikning av data løftet fram på stadig mer sofistikerte måter.

Det kan også se ut til at elevenes uttalelser for det meste kan defineres som det Sandoval (2005) kaller formell epistemologi, altså refleksjoner om profesjonell eller formell naturvitenskap. Han hevder at forskning på elevers naturvitenskapelige epistemologi også bør inkludere analyser av elevenes egne ideer når de utfører utforskende arbeidsmåter, for på den måten å bygge en bro mellom praktisk epistemologi og formell epistemologi. Elevene i denne studien fikk få konkrete spørsmål for å avdekke epistemologiske ideer mens de gjorde utforskende arbeid. Flere studier indikerer at selv om elevene deltar i en utforskende klasseromspraksis og dermed deltar i aktiviteter som ligner på det som forskere innenfor naturvitenskapene gjør, opprettholder de naive epistemologiske ideer (Khishfe \& Abd-El-Khalick, 2002; Meichtry, 1992; Moss, Abrams, \& Robb, 2001; Sandoval \& Morrison, 2003).

Mye tyder på at noen elever vil kunne utvikle en mer avansert naturvitenskapelig epistemologi hvis de blir utfordret mens de deltar i utforskende arbeidsmåter. Det ville være interessant å undersøke hvilken effekt det vil ha for elevene å reflektere over utforskende arbeidsmåter i mange sammenhenger over lengre tid. I en slik kontekst kan både elevenes praktiske og formelle epistemologi undersøkes, og en kan finne ut hvordan epistemologiske ideer og evne til utforskende arbeid påvirker hverandre.

\section{Referanser}

Abd-El-Khalick, F. (2013). Teaching With and About Nature of Science, and Science Teacher Knowledge Domains. Science \& Education, 22(9), 2087-2107.

Asay, L., \& Orgill, M. (2010). Analysis of essential features of inquiry found in articles Published in the The Science Teacher, 1998-2007. Journal of Science Teacher Association, 21(1), 57-79. 
Carey, S., \& Smith, C. (1993). On understanding the nature of scientific knowledge. Educational Psychologist, 28(3), 235-251.

Crawford, B. (2007). Learning to teach science as inquiry in the rough and tumble of practice. Journal of Research in Science Teaching, 44(4), 613-642.

Driver, R., Leach, J., Millar, R., \& Scott, P. (1996). Young People's Images of Science. Buckingham: Open University Press.

Grosslight, L., Unger, C. M., Jay, E., \& Smith, C. (1991). Understanding models and their use in science: Conceptions of middle and high school students and experts. Journal of Research in Science Teaching, 28, 799-822.

Haug, B. (2014). Inquiry-Based Science: Turning Teachable Moments into Learnable Moments. Journal of Science Teacher Education, 25 (1), 79-96 doi: 10.1007/s10972013-9375-7

Hogan, K., \& Maglienti, M. (2001). Comparing the epistemological underpinning of students' and scientists' reasoning about consclusions. Journal of Research in Science Teaching, 38(6), 663-687.

Khishfe, R., \& Abd-El-Khalick, F. (2002). The influence of explicit reflective versus implicit inquiryoriented instruction on sixth graders' views of nature of science Journal of Research in Science Teaching, 39(7), 551-578.

Kolstø, S. D. (2006). Et allmenndannende naturfag. Fagets betydning for demokratisk deltakelse. NorDiNa, 5, 82-99.

Lederman, N. G., Abd-El-Khalick, F., Bell, R. L., \& Schwartz, R. S. (2002). Views of nature of science questionaire: toward valid and meaningful assesment of learners' conceptions of nature of science. Journal of Research in Science Teaching, 39(6), 497-521.

Linn, M. C., \& Songer, N. B. (1993). How do students make sense of science? Merill-Palmer Quarterly, 39(1), 47-73.

Meichtry, Y. J. (1992). Influencing student understandingof the nature of science: Data from a case of curriculum development. Journal of Research in Science Teaching, 29(4), 389407.

Minner, D. D., Levy, A. J., \& Century, G. (2010). Inquiry-based science instruction - What is it and does it matter? Results from a research synthesis year 1984-2002. Journal of Research in Science Teaching, 47(4), 474-496.

Moss, D. M., Abrams, E. D., \& Robb, J. (2001). Examinig student conceptions of the nature of science. International Journal of Science Education, 23(8), 771-790.

Perry, W. (1970). Forms of intellectual and ethical development in the college years. New York: Holt, Rinehart \& Winston.

Peters, E., \& Kitsantas, A. (2010). The effect of nature of science metacognitive prompts on science students' content and nature of science knowledge, metacognition, and selfregulatory efficacy. School Science and Mathematics, 110(8), 382-396.

Postholm, M. B. (2010). Kvalitativ metode: en innføring med fokus på fenomenologi, etnografi og kasusstudier. Oslo: Universitetsforlaget.

Rudolph, J. L. (2005). Epistemology for the masses: The origins of the "scientific method" in American schools. History of Education Quarterly, 45(2), 341-376.

Sandoval, W. A. (2005). Understanding students' practical epistemologies and their influence on learning through inquiry. Science Education, 89(634-656).

Sandoval, W. A., \& Morrison, K. (2003). High Scool students' ideas about theories and theory change after a biological inquiry unit. Journal of Research in Science Teaching, 40(4), 369-392. 
Schauble, L., Glaser, R., Duschl, R., Schulze, S., \& John, J. (1995). Students' understanding of the objectives and procedures of experimentation in the science classroom. Journal of the Learning Sciences, 4(2), 131-166.

Sjøberg, S. (2009). Naturfag som allmenndannelse en kritisk fagdidaktikk (3. utg. ed.). Oslo: Gyldendal akademisk.

Smith, C., Maclin, D., Houghton, C., \& Hennessey, M. G. (2000). Sixth-grade students' epistemologies of science. The impact of school science experiences on epistemological development. Cognition and Instruction, 18(3), 349-422.

Smith, C., \& Wenk, L. (2006). Relations among three aspects of first-year college students` epistemologies of science. Journal of Research in Science Teaching, 43(8), 747-785.

Thagaard, T. (2009). Systematikk og innlevelse : en innføring i kvalitativ metode. Bergen: Fagbokforl.

Utdanningsdirektoratet. (2013). Lareplan i naturfag. Olso: Utdanningsdirektoratet Retrieved from http://www.udir.no/k106/NAT1-03/Hele/Formaal/.

Wu, H. K., \& Wu, C. L. (2011). Exploring the Development of Fith Graders' Practical Epistemologies and Explanation Skill in Inquiry-Based Learning Classrooms. Research in Science Education, 41, 319-340.

Yacoubian, H. A., \& BouJaoude, S. (2010). The effect of reflective discussions following inquiry-based laboratory activities on students' views of nature of science. Journal of Research in Science Teaching, 47(10), 1229-1252.

Øyehaug, A. B., \& Holt, A. (2013). Sammenhengen mellom naturvitenskapelig produkt og prosess. En studie av dialoger fra utforskende arbeid i naturfag relatert til stoffer og stoffers endringer. Nordina, 1(9), 33-49. 